\title{
Seaweed aquaculture: cultivation technologies, challenges and its ecosystem services
}

\author{
Jang K. Kim ${ }^{1,2}$, Charles Yarish ${ }^{3, *}$, Eun Kyoung Hwang ${ }^{4}$, Miseon Park ${ }^{5}$ and Youngdae Kim ${ }^{5}$ \\ ${ }^{1}$ Department of Marine Science, School of Natural Sciences, Incheon National University, Incheon 22012, Korea \\ ${ }^{2}$ Department of Marine Sciences, University of Connecticut, 1 University Place, Stamford, CT 06901, USA \\ ${ }^{3}$ Department of Ecology \& Evolutionary Biology, University of Connecticut, 1 University Place, Stamford, CT 06901, USA \\ ${ }^{4}$ Seaweed Research Center, National Institute of Fisheries Science, Mokpo 58746, Korea \\ ${ }^{5}$ Southeast Sea Fisheries Research Institute, National Institute of Fisheries Science, Tongyeong 46083, Korea
}

Seaweed aquaculture technologies have developed dramatically over the past 70 years mostly in Asia and more recently in Americas and Europe. However, there are still many challenges to overcome with respect to the science and to social acceptability. The challenges include the development of strains with thermo-tolerance, disease resistance, fast growth, high concentration of desired molecules, the reduction of fouling organisms and the development of more robust and cost efficient farm systems that can withstand storm events in offshore environments. It is also important to note that seaweed aquaculture provides ecosystem services, which improve conditions of the coastal waters for the benefit of other living organisms and the environment. The ecosystem services role of seaweed aquaculture and its economic value will also be quantitatively estimated in this review.

Key Words: ecosystem services; Eucheuma; Gracilaria / Gracilariopsis; Kappaphycus; kelp; Pyropia / Porphyra; Sargassum; seaweed aquaculture

\section{INTRODUCTION}

According to an archaeological study, cooked and partially eaten seaweeds have been found at a 14,000-yearold site in southern Chile, suggesting seaweed have been part of the human diet in the Western Hemisphere for a very long time (Dillehay et al. 2008). In the past four hundred years, seaweeds have been an important part in Asian cuisine more so than in western cultures. Global seaweed aquaculture production occupies approximately $20 \%$ of the total world marine aquaculture production by weight, with an annual value of US $\$ 6.7$ billion in 2013 (Bjerregaard et al. 2016, Cottier-Cook et al. 2016, FAO 2017). Most production occurs in Asia. Seaweed aquacul- ture production is dominated ( $>81 \%$ of total production) by relatively few species: the brown kelps, Saccharina japonica and Undaria pinnatifida; and the red seaweeds including Pyropia / Porphyra spp. ('nori' in Japanese or 'gim' in Korean), Kappaphycus alvarezii and Eucheuma striatum (carrageenophytes) and Gracilaria / Gracilariopsis spp. (agarophytes).

Currently 54,000 tons of seaweed are cultivated in the Americas and Europe with an annual value of US $\$ 51$ million in 2014 (FAO 2017), which is less than the value of seaweed products that Korea exported to the United States during the same period (US $\$ 67$ million) (Meekyi-
(9) $\$$ This is an Open Access article distributed under the terms of the Creative Commons Attribution Non-Commercial License (http://creativecommons.org/licenses/by-nc/3.0/) which permits unrestricted non-commercial use, distribution, and reproduction in any medium, provided the original work is properly cited.
Received December 13, 2016, Accepted March 3, 2017

* Corresponding Author

E-mail: charles.yarish@uconn.edu

Tel: +1-203-251-8432, Fax: +1-203-251-8592 
ung Kim, Korea Agro-Trade Center personal communication). Although seaweed aquaculture is a relatively new industry in North America and Europe, the demand by western markets is expected to increase rapidly due to consumer desire for new protein sources and healthy food supplements, plus food industry's interest in sustainable textural additives and food security.

Seaweed aquaculture technologies have developed dramatically in Asia, but there are still many challenges to overcome. These challenges vary for different species and in different countries. In this study, we will discuss the challenges to seaweed cultivation of major aquacultured species. Seaweed aquaculture also provides ecosystem services through nutrient removal upon harvest. This ecosystem services role by seaweed aquaculture will also be addressed in this study.

\section{CULTIVATION TECHNOLOGIES AND CHALLENG- ES IN MAJOR AQUACULTURED SPECIES}

\section{Pyropia / Porphyra ('nori' or 'gim')}

Pyropia / Porphyra has been cultivated for the past several hundred years in Japan and has become one of the most successful aquaculture industries in Japan, Korea, and China (Mumford and Miura 1988, Pereira and Yarish 2008). Its current annual value is nearly $\$ 0.95$ billion (FAO 2017). Pyropia / Porphyra has the highest commercial value per unit mass ( $\$ 523$ per wet metric ton) in comparison to other aquacultured species, kelp, \$141 per wet ton; Gracilaria, \$273 per wet ton; Kappaphycus / Eucheuma, \$172 per wet ton; and Sargassum, \$460 per wet ton (FAO 2017). Although total 138 species of Pyropia and Porphyra are currently accepted taxonomically (Guiry and Guiry 2016), only 3 major species (Py. yezoensis, $P y$. tenera, and $P y$. haitanensis) have been commercially cultivated, mostly in China, Korea, and Japan $(99.99 \%$ of total production) (FAO 2017). The culture methods of Pyropia / Porphyra in these three countries are basically similar, with minor modifications (see Sahoo and Yarish 2005, Pereira and Yarish 2008, 2010, Pereira et al. 2013 for more details). For example, some farmers use free-living conchocelis for seeding while others use conchocelis on oyster shells (He and Yarish 2006, He et al. 2008). Seedlings may be outplanted in the open water farms using one of three cultivation methods: fixed pole, semifloating raft, or floating raft (see Sahoo and Yarish 2005 for details). The epiphyte control techniques are also different based on the cultivation techniques. Most Chinese farms, and some Korean and Japanese farms use desiccation control methods by exposing the Pyropia / Porphyra nets to the air to kill epiphytes and competing organisms (e.g., Ulva spp.), while most Korean and Japanese farmers prefer to use a pH control method by applying organic acids onto the nets (Pereira and Yarish 2010, Kim et al. 2014a) but this is a costly approach. There are no additional (or minimal) costs using the desiccation method and this method may even increase the protein content in tissue (Kim et al. 2013b). However, the desiccation method is not as efficient as the $\mathrm{pH}$ control method. Uncontrolled fouling organisms reduce the quality of production. Recent reports even suggest that the source of the world largest macroalgal blooms originated from Ulva grown on the rafts of Pyropia farms in the Southern Yellow Sea of China (Liu et al. 2009, Hu et al. 2010, Zhang et al. 2014, 2016, Huo et al. 2016).

Pyropia / Porphyra has been cultivated in the western countries since 1980s; however, production has had limited success. In 1994, the first commercial attempt to cultivate Pyropia yezoensis ('Porphyra') in open water in the State of Maine (Chopin et al. 1999, McVey et al. 2002) was unsuccessfully attempted by Coastal Plantations International (later incorporated into PhycoGen, Inc., Portland, ME, USA). The aquaculture site had insufficient nutrients to support vigorous growth of Py. yezoensis. In 1996, this company moved its nori nets adjacent to an Atlantic salmon (Salmo salar) farm at the Connors Aquaculture Inc. facilities (Deep Cove, Eastport, ME, USA). This open water cultivation was successful and ultimately lead to the development of Integrated Multi-Trophic Aquaculture (IMTA). However, PhycoGen, Inc., went bankrupt due to the downturn in the investment environment. More recently, Porphyra umbilicalis cultivation is in process in Maine by Brawley and her colleagues (Blouin et al. 2011, Brawley, University of Maine, personal communication). A cultivation manual has also been published for seedstock production of Pyropia / Porphyra in the United States (Redmond et al. 2014a) with accompanying videos in English and Spanish. These efforts reflect that the western countries are interested in Pyropia / Porphyra cultivation. However, Pyropia / Porphyra cultivation is still in its nascent stage in the western countries, and there currently are no commercial Pyropia / Porphyra growers in the United States. Therefore, it is critical to develop local cultivars and cultivation techniques suitable for the local environments and boutique markets. Selective (intraspecific and inter-specific) breeding of cultivated Pyropia I Porphyra has been intensively studied in Asia (Miura 1984, Shin 1999, 2003, Niwa et al. 2009). Genetic improve- 
ment has developed superior strains with higher growth capacity, better flavor, darker color and higher tolerance to diseases (Chen et al. 2015).

The effects of climate change may be an incentive to do more research in genetic manipulations. Recently, National Aeronautics and Space Administration (NASA) and National Oceanic and Atmospheric Administration (NOAA) reported the year 2016 ranks as Earth's warmest since 1880. The 17 warmest years on record, with the exception of 1998, have occurred since 2000. Since 1880, Earth's average surface temperature has risen by about $1.1^{\circ} \mathrm{C}$ and the majority of that warming has occurred in the past three decades (NASA 2017). Therefore, development of new strains with high thermo-tolerances will be a must for the development of a sustainable seaweed aquaculture industry.

\section{Gracilaria / Gracilariopsis}

The red algae Gracilaria / Gracilariopsis are two of the world's most cultivated seaweeds with over 3.8 million tons of annual production and worth annually about US $\$ 1$ billion (FAO 2017). Gracilaria / Gracilariopsis have been mostly cultivated in two Asian countries (China 70\% and Indonesia $28 \%$ of global production). In the Americas, Chile is the most productive country, producing more than 12.8 tons per year with an annual value of US $\$ 29$ million (FAO 2017). Most of the biomass is used in the phycocolloid industry as the main source of food grade agar (Pereira and Yarish 2008) and as an animal feed (Qi et al. 2010, Johnson et al. 2014). Gracilaria / Gracilariopsis contribute approximately $66 \%$ of the total agar production (Pereira and Yarish 2008). Currently 185 Gracilaria and 24 Gracilariopsis species are accepted taxonomically (Guiry and Guiry 2016). Gracilaria / Gracilariopsis include warm temperate to subtropical eurythermal species. These species are easy to propagate (asexually and sexually), and have relatively high growth rates (Abreu et al. 2011a, Kim and Yarish 2014, Kim et al. 2015c, 2016, Wu et al. 2015, Gorman et al. 2017). Gracilaria / Gracilariopsis are also euryhaline species, which can tolerate a wide range of salinities, from about 10-40 psu, though they grow best in ranges of 25-33 psu (Yokoya et al. 1999, Weinberger et al. 2008, Kim et al. 2016, Gorman et al. 2017). They can survive temperature ranges from $0-35^{\circ} \mathrm{C}$ but have an optimal range of $20-28^{\circ} \mathrm{C}$ (Yokoya et al. 1999, Raikar et al. 2001, Abreu et al. 2011a, Kim et al. 2016).

Gracilaria / Gracilariopsis have been cultivated mainly in four different ways, including open water rope cultivation, near shore bottom cultivation, pond culture and tank cultures (see Oliveira et al. 2000, Sahoo and Yarish 2005, Pereira and Yarish 2008 for more details). In any of these methods, providing sustainable seedstock is critical. Currently, most Gracilaria / Gracilariopsis seedstock has been supplied from the wild (either collection of healthy branches of Gracilaria / Gracilariopsis from natural stock or selection of reproductive plants to collect spores (either carpospores or tetraspores) for seeding (Buschmann et al. 2008a). Dependence on natural stocks may cause some serious problems including physiological variations (e.g., growth, agar content, etc.) in the seedstock. Adequate measures should be taken to protect natural stocks of Gracilaria / Gracilariopsis from over-exploitation of donor populations. Another methodology that could be used is nursery (tank culture) systems to provide sufficient seedstock through vegetative propagation (Hanisak 1987, Abreu et al. 2011a, 2011b, Kim and Yarish 2014). One important advantage of tank cultivation is the ease of controlling the culture system (Abreu et al. 2011b, Pereira et al. 2013). This ensures that production meets high quality standards and biosafety for human consumption and other high value production applications for the cosmeceutical and pharmaceutical industries. A limitation for tank culture, however, is high management costs (Hanisak and Ryther 1984, Caines et al. 2014). Recently, Abreu et al. (2011b) have used tank cultivation to mitigate fish effluent, therefore reducing the production costs. Kim and Yarish (2014) has also suggested other cost efficient resources, such as injecting $\mathrm{CO}_{2}$ and using commercial fertilizers. The use of LED lighting could further reduce tank cultivation costs (Kim et al. 2015c). There was an intensive study on genetics, mutation, selective breeding and even genetic engineering in Gracilaria / Gracilariopsis by van der Meer and his collaborators a few dacades ago (see Patwary and van der Meer 1992 and references therein). More recently in Chile, strains of Gracilaria chilensis were established and maintained without sexual reproduction. These strains are homogeneous clonal cultures (Buschmann et al. 2008a, Guillemin et al. 2008, Robinson et al. 2013), which can be more susceptible to diseases outbreaks and environmental changes. The quality of wild Gracilaria / Gracilariopsis in recent years has been diminished due to declines in the cultivation environments and increase in diseases (Alamsjah 2010). Using asexually derived branches may lead to a reduction in genetic variability but more work needs to be done on the population genetics of these taxa.

Therefore, the technology development combining hybridization, genetic material establishment while maintaining genetic diversity will become very important in 
Gracilaria / Gracilariopsis aquaculture. Another challenge in Gracilaria / Gracilariopsis aquaculture is to develop technologies and strategies to reduce fouling problems. Fouling organisms (e.g., epiphytes, tunicates, hydroids, etc.) have been observed at Gracilaria farms in Long Island Sound (CT), Bronx River estuary (NY), and Waquoit Bay (MA) (Kim et al. 2014b, Lindell et al. 2015). A few successful solutions to these problems include fresh water rinses, the use of tank grown fresh Gracilaria seedstock, determination of optimal stocking density and photon fluence levels. However, more studies are needed for sustainable production and to understand the genetic variability of the seedstocks.

\section{Kappaphycus and Eucheuma}

The red algae Kappaphycus and Eucheuma, major sources of carrageenan, account for over $80 \%$ of world's carrageenan production (Pereira and Yarish 2008, Hayashi et al. 2010). Approximately 10.75 million tons of these species were produced worth over US $\$ 1.9$ billion in 2014 (FAO 2017). Kappaphycus and Eucheuma have been cultivated mostly in Indonesia (over 9.0 million tons, over 83\% of global production, mostly Eucheuma), followed by the Philippines (nearly 1.4 million tons, $13 \%$ of global production, mostly Kappaphycus). Approximately 340,000 tons of these carrageenophytes were also cultivated in Malaysia, Cambodia / Vietnam, China, Tanzania / Madagascar, Belize and Brazil (Valderrama et al. 2015, Bjerregaard et al. 2016, FAO 2017).

Of six species taxonomically accepted as Kappaphycus and 30 Eucheuma species, Kappaphycus alvarezii and Eucheuma denticulatum are most often cultivated. Both of these taxa are cultivated using the same methodologies including the fixed, off-bottom line method, the floating raft method and basket method (see Ask and Azanza 2002, Pereira and Yarish 2008, Hayashi et al. 2010 for more details). The steps in the farming of these genera include 1) site selection, 2) selection of cultivation methodology, 3) farm maintenance, and 4) harvesting and drying. Among these steps, site selection is most important due to the herbivory of siganids (rabbitfish) and puffers. Turtles are also problematic because they take large bites and also crawl through a farm, causing physical damage to the farm systems. Long-spined sea urchins may also be a pest and can cause injuries to the farmers as they try to remove them. There is no simple solution except moving to another site where these animals are not prevalent. Diseases are also a challenge. The most common disease of the euchemoid spp. is called "ice-ice" because the ap- pearance of white segments on the thalli, causing them to break (Largo et al. 1995, Ask and Azana 2002, Vairappan et al. 2009). It is still unknown what vector causes this disease, but a bacterial or viral infection, and / or physical stresses have been suggested as the potential sources (Vairappan et al. 2009). Farmers also need to remove epiphytes 2-3 times each and every week, which requires intensive labor (Hurtado et al. 2006). Therefore, it is extremely important to develop new strains that are light and thermally tolerant and disease resistant. More efficient epiphyte control also needs to be developed. In addition, storm damage due to typhoons is problematic in tropical regions where cultivation occurs. The simplest solution to minimize storm damage is the removal of all cultivation systems prior to the typhoon season $(\sim 3$ months per year). Development of more robust and cost efficient farm systems are needed especially in the offshore environment.

\section{Kelp (Saccharina and Undaria)}

Over 8.0 million tons of kelp were cultivated and harvested in 2014 with a value of about US \$1.4 billion annual values (FAO 2017). Nearly all kelp production occurred in Asia: China 88.3\%; Korea (south) 6.6\%; and Korea (north) 4.4\% (FAO 2017). Kelp has been utilized mostly for human consumption, but recently, it also has been increasingly utilized as abalone feed due to low production costs (Hwang et al. 2012, 2013). Since the early part of this decade, Undaria and Saccharina production have continuously increased due to demand for abalone feeds in Korea (Hwang et al. 2012). Over $60 \%$ of total production of Saccharina and Undaria was used in the abalone industry in 2012 (Hwang et al. 2012).

In Western countries, kelp species (primarily the sugar kelp, Saccharina latissima and winged kelp, Alaria esculenta) have been cultivated during the last two decades in the North Atlantic Ocean (e.g., the United States, Canada, Iceland, Norway, Scotland, Ireland, Sweden, and Germany, etc.) (Buck and Buchholz 2004, Barrington et al. 2009, Broch et al. 2013, Kraemer et al. 2014, Kim et al. 2015b, Marinho et al. 2015) and Macrocystis, Saccharina latissima, and Alaria esculenta in the eastern Pacific Ocean (e.g., Chile: Buschmann et al. 2008b, 2014, Camus et al. 2016, Correa et al. 2016, Valero et al. 2017; Alaska: Stekoll and Peeples 2016). The kelp aquaculture industry in the western countries has become one of the fastest growing industries (Cottier-Cook et al. 2016).

For both Saccharina and Undaria, cultivation begins with zoospores (meiospores) for seeding. The seeding 
methods are a bit different between Asia (use of seed frames) and the West (use of seedspools) (Pereria and Yarish 2008, Redmond et al. 2014a) mainly due to the nursery capacities and the scale of operations of the open water farms. However, the open water cultivation techniques using longlines are very similar. Once the seedstring is outplanted at open water farms the kelp thalli will grow up to $2-5 \mathrm{~m}$ in length, but sometimes may grow up to 10 $\mathrm{m}$ (see Pereira and Yarish 2008, Redmond et al. 2014a, SINTEF 2014 for details).

Dealing with climate change will be a challenge for cultivation of cool temperate species of kelp (Park et al. 2017). Efforts to develop strains of kelp with traits of fast growth, disease resistance and high temperature tolerance are needed. Selective breeding and intensive selection of kelp strains in Asia, however, have reduced the genetic diversity and narrowed the germplasm base of the varieties in cultivation (Kawashima and Tokuda 1993, Li et al. 2007, 2016, Robinson et al. 2013), therefore jeopardizing the industry expansion in Asia.

In the United States, Canada and Europe, strain development will be a challenge. Meiospore "seeds" (zoospores) have relied mostly on natural populations. Development of "seedbanks" for the kelp species will provide a sustainable and reliable source of seedstock without impacting the natural beds of the kelp. Having the seaweeds with desirable morphological and physiological traits will also enhance production capacity of the seaweed industry. Another challenge in these countries is permitting and the social syndrome known as NIMBY ("Not In My Back Yard") reactions. For example, in the United States at least 120 federal laws were identified that affect aquaculture either directly (50 laws) or indirectly (70 laws) and more than 1,200 state statutes regulate aquaculture in 32 states (Getchis et al. 2008). Regulatory complexity is further increased when towns or counties are given jurisdiction over local waters. Social resistance has also been major factor limiting the growth of aquaculture in the United States (Getchis et al. 2008). The nearshore waters of the United States are heavily used, having both recreational (boating, fishing, swimming) and aesthetic (ocean and bay views from waterfront homes) values. Due to this reason, offshore cultivation has been suggested as an alternative to avoid stakeholder conflicts (Langan and Horton 2005, Rensel et al. 2011).

Recently, the U.S. Department of Energy's Advanced Research Projects Agency-Energy (ARPA-E) has expressed interest in offshore seaweed aquaculture for the production of feeds, fuels and chemicals. The potential species discussed include Saccharina in the Northeast (Western
Atlantic Ocean), Northwest (eastern Pacific Ocean of Washington and Alaska) and Sargassum spp. in the Gulf of Mexico and Caribbean. To achieve success in these ventures, technology development will be required, including breeding for suitable strain development, cultivation, harvesting, transport, storage, processing, ecosystem services and product opportunities for long-term financial viability of a United States-based macroalgae industry on the path to biofuels. The nutrients for the growth of seaweeds may also be limited in the offshore environment. To resolve this issue, site selection for cultivation will be critical, such as in upwelling areas. The offshore seaweed farms are unlikely to experience conflicts with other economic and recreational uses, which may result in fewer restrictions on farm size and greater economies of scale. Considering current cultivation techniques, the kelp will be most the appropriate species to cultivate offshore due to its low requirement for maintenance and harvest in comparison to other aquacultured species. For example, an endemic kelp phenotype, known as Saccharina latissima forma angustissima (F. S. Collins) A. Mathieson could be an ideal candidate for the offshore cultivation. This endemic form grows only at wave-impacted locations in Maine (Mathieson et al. 2008, Augyte et al. in press). Unlike the common Saccharina latissima plants, this endermic form grows very narrow $(2-5 \mathrm{~cm})$ and long $(\sim 5 \mathrm{~m})$, which is probably induced by hydrodynamic forces and mechanical stress from breaking waves and strong currents (Fowler-Walker et al. 2006, Koehl et al. 2008). These features will make Saccharina latissima forma angustissima more suiatable for the offshore cultivation.

\section{Sargassum}

Sargassum is the most common brown macroalgae found in temperate, tropical, and subtropical waters worldwide. These seaweeds are adapted to many different oceanic environments with a wide variety of forms and reproductive strategies (Guiry and Guiry 2016). Sargassum species have traditionally been utilized for food and medicine in Asia. They continue to be wild harvested and cultivated in Japan, China, and Korea, for human consumption as sea vegetables and for use as a medicinal "seaweed herbs." Locally known as the "black vegetable" in China, Sargassum is valued for its high nutritional content and nutty flavor. It is added to salads, soups or vegetable dishes (Xie et al. 2013). Sargassum is utilized in Chinese medicine as an expectorant for bronchitis, and to treat laryngitis, hypertension, infections, fever, and goiter (Hou and Jin 2005). Sargassum fusiforme (formally 
"Hizikia fusiformis") cultivation was initiated in the early 1980s. Thus, the production and economic value is still low, approximately 175,000 tons of production worth US $\$ 80$ million in 2014 (FAO 2017). Nearly all Sargassum is produced in China. Although still low in production, its commercial value per unit mass is very high (US $\$ 460$ per wet ton), which is the highest amongst the aquacultured brown seaweeds. It is even comparable to Pyropia / Porphyra (US \$523 per wet ton). Currently, several Sargassum species are cultured in Asia, including S. thunbergii, $S$. fulvellum, S. muticum, and S. horneri in China (Xie et al. 2013), and S. fusiforme and S. fulvellum in Korea (Hwang et al. 2006a).

Traditional culture methods initially relied on the use of wild seedlings collected from natural beds. Groups of 3-4 seedlings, $5-10 \mathrm{~cm}$ in length, were inserted into seeding rope at intervals of $5-10 \mathrm{~cm}$. This smaller seeding line was then attached to a main longline placed at depths of 2-3 m, and cultivated from November to May (Sohn 1998, Hwang et al. 2006a, Redmond et al. 2014b). This dependence on wild seedlings resulted in overharvesting natural beds, so new culture methods were developed. Holdfast-derived seeding was the first step towards developing culture techniques for Sargassum. This type of culture takes advantage of the perennial nature of the holdfast, allowing farmers to reuse the holdfasts from the previous year's crops (Hwang et al. 1998). While plants may still be sourced from wild beds, the attached holdfasts can be reused for the next season's crop by over-summering in the sea after harvest until the next growing season. While this allows for reuse of existing cultured plants, the resulting harvestable biomass tends to diminish after each year. Today, Sargassum lines are seeded with juvenile plants obtained from reproductive adults. Obtaining seedlings through sexual reproduction allows for mass production of new plants for seeding, and results in higher biomass yields (Hwang et al. 2006b, Peng et al. 2013, Redmond et al. 2014b). Fertilized eggs are gathered from mature fronds and "seeded" onto seedstring by allowing juveniles to attach to seed lines with newly forming rhizoids. Once attached, seedlings are cultured in a nursery until ready for out-planting at sea, where they are transferred to submerged long lines until harvest. The attached holdfasts can also be re-used for multiple years without any further initiation of culture ropes. This is economically reasonable cultivation method, but fouling organisms are problematic. Technology development to reduce fouling is an urgent need for the sustainable production and the growth of the Sargassum aquaculture industry.

\section{ECOSYSTEM SERVICES}

Seaweeds are valued as food in many parts of Asia and in the western countries. Seaweeds are also used to produce animal feed, chemicals, paper, fertilizer, biofuel, and other renewable, derivative products, and even to test biological toxicity for human and environmental health (Han et al. 2011, Johnson et al. 2014, Hafting et al. 2015, Kerrison et al. 2015, Park et al. 2016, Wells et al. 2016). One goal for the development of sustainable aquaculture is to ensure that commercial aquaculture has minimal adverse effects on the environment. One way to achieve this goal is through development of improved methods of waste management for land based and coastal / offshore aquaculture. IMTA combines the fed aquaculture (e.g., fish or shrimp) with the extractive aquaculture (seaweed and shellfish) to create a more balanced ecosystem. In coastal waters, high levels of these nutrients can trigger harmful algal blooms and contribute to excessive growth of nuisance or opportunistic macroalgae, which in turn have negative consequences on coastal ecosystems and economies (Neori et al. 2004, Buschamann et al. 2008a, Chopin et al. 2008, Pereira and Yarish 2008, Abreu et al. 2009, 2011b, Kim et al. 2015a). Nutrient bioextraction is a similar concept but without the fed aquaculture component. The concept of nutrient bioextraction can be applied to urbanized estuaries, where the excess nutrients are already problematic. In the IMTA and the nutrient bioextraction systems (whether land based, coastal or offshore) seaweed can be used as an extractive component to remove inorganic nutrients and mitigate potentially adverse environmental impacts (Neori et al. 2004, 2007, Corey et al. 2012, 2014, Kim et al. 2013a, 2014b, 2015b, Rose et al. 2015, Wu et al. 2017). Seaweeds take up nitrogen, phosphorus and carbon dioxide, which they use for growth and production of energy storage products. When seaweeds are harvested from the IMTA or nutrient bioextraction systems, the nutrients are also being removed from the water.

Considering the global seaweed production and tissue carbon and nitrogen contents in each species, total extractive nitrogen and carbon by seaweed aquaculture can be estimated. Considering average values of nitrogen (Pyropia / Porphyra 5.5\%, Gracilaria 3.0\%, Kappaphycus / Eukeuma 1.7\%, kelp 2.0\%, and Sargassum 4.1\%) and carbon (Pyropia / Porphyra 38\%, Gracilaria 28\%, Kappaphycus / Eukeuma 29\%, kelp 30\%, and Sargassum 34\%) (Asare and Harlin 1983, Gerald 1997, Schaffelke and Klumpp 1998, Gevaert et al. 2001, Schaffelke 2001, Chung et al. 2002, Rawson et al. 2002, Sahoo and Ohno 
2003, Dean and Hurd 2007, Kim et al. 2007, 2014b, 2015b, Buschmann et al. 2008b, Abreu et al. 2009, RobertsonAndersson et al. 2009, Levine and Sahoo 2010, Broch et al. 2013), the total nitrogen and carbon removal by these five major aquaculture groups is approximately 65,000 tons of nitrogen per year and 760,000 tons of carbon per year (to 2.8 million tons of $\mathrm{CO}_{2}$ ), respectively. Over 120 million tons of fertilizer was used in 2014 and approximatelty 15$30 \%$ of it entered the ocean (FAO 2015). Recently, Bjerregaard et al. (2016) reported that seaweed aquaculture could remove approximately $30 \%$ of the introduced nitrogen if seaweeds were aquacultured in $0.03 \%$ of the ocean surface area, producing 500 million tons DW. They also estimated that approximately 135 million tons of carbon could be removed by the same amount of aquacultured seaweed. This carbon removal is approximately $3.2 \%$ of the carbon input to seawater from greenhouse gas emissions annually. The ecosystem services role provided by seaweed aquaculture often falls unnoticed by coastal managers, partly because the seaweeds are hidden underwater, and partly because the services themselves are not yet accurately valued by markets (Barbier 2013, Costanza et al. 2014). The additional ecosystem benefits of seaweed aquaculture need further study and dissemination via print and social media channels.

\section{FUTURE DIRECTIONS}

Seaweed aquaculture technologies have developed dramatically over the last several decades, but there are still challenges to overcome. New strain development by advanced breeding tools is the most urgent challenge. Superior strains will allow the growers to expand growing seasons and enhance production. Considering the global climate challenges, development of thermo-tolerant strains may be needed. Also the strains with disease resistance, fast growth, high concentration of desired molecules, the reduction of fouling organisms also need to be developed. Development of advanced cultivation technologies which are more robust and cost efficient farm systems is very important. This new system will be even more critical for highly exposed, off-shore environments since most seaweed aquaculture have occurred nearshore. With offshore aquaculture, new designs and approaches to macroalgae cultivation will be required, including strain development, harvesting, transport and processing. The offshore aquaculture system may leverage new material and engineering solutions, autonomous and robotic technologies, as well as advanced sensing and monitoring capabilities.

\section{ACKNOWLEDGEMENTS}

This study was supported by grants to C. Yarish and J. K. Kim from the U.S. EPA Long Island Sound Study's Long Island Sound Futures Fund, National Fish and Wildlife Foundation (NFWF/Legacy Grant Project ID: 1401.12.03305), Connecticut Sea Grant College Program (R/A-38 and R/A-39), the U.S. EPA Long Island Sound Study's Long Island Sound Futures Fund, National Fish and Wildlife Foundation (NFWF/Legacy Grant Project ID: 1401.13.039525), NOAA SBIR I and II (Contract \# WC133R10CN0221), USDA/National Institute of Food and Agriculture (NIFA) Award \# 2014-70007-22546), the United States-Israel Binational Agricultural Research and Development Fund (BARD; US- 4599-13 R), and a grant to M. Park, Y. Kim and J. K. Kim from the National Institute of Fisheries Science (R2017015), Republic of Korea.

The authors would like to acknowledge NOAA-Ministry of Oceans and Fisheries (MOF) of Korea Joint Project Agreement on Integrated Multi-Trophic Aquaculture, through the Joint Coordination Panel for Aquaculture Cooperation for US-Korea.

\section{REFERENCES}

Abreu, M. H., Pereira, R., Buschmann, A. H., Sousa-Pinto, I. \& Yarish, C. 2011a. Nitrogen uptake responses of Gracilaria vermiculophylla (Ohmi) Papenfuss under combined and single addition of nitrate and ammonium. J. Exp. Mar. Biol. Ecol. 407:190-199.

Abreu, M. H., Pereira, R., Yarish, C., Buschmann, A. H. \& Sousa-Pinto, I. 2011b. IMTA with Gracilaria vermiculophylla: productivity and nutrient removal performance of the seaweed in a land-based pilot scale system. Aquaculture 312:77-87.

Abreu, M. H., Varela, D. A., Henríquez, L., Villarroel, A., Yarish, C., Sousa-Pinto, I. \& Buschmann, A. H. 2009. Traditional vs. integrated multi-trophic aquaculture of Gracilaria chilensis C. J. Bird, J. McLachlan \& E. C. Oliveira: productivity and physiological performance. Aquaculture 293:211-220.

Alamsjah, M. A. 2010. Producing new variety of Gracilaria sp. through cross breeding. Res. J. Fish. Hydrobiol. 5:159167.

Asare, S. O. \& Harlin, M. M. 1983. Seasonal fluctuations in tissue nitrogen for five species of perennial macroalgae in Rhode Island Sound. J. Phycol. 19:254-257.

Ask, E. I. \& Azanza, R. V. 2002. Advances in cultivation technology of commercial eucheumatoid species: a re- 
view with suggestions for future research. Aquaculture 206:257-277.

Augyte, S., Yarish, C., Redmond, S. \& Kim, J. K. Cultivation of a morphologically distinct strain of the sugar kelp, Saccharina latissima forma angustissima, from coastal Maine, USA, with implications for ecosystem services. J. Appl. Phycol. (in press).

Barbier, E. B. 2013. Valuing ecosystem services for coastal wetland protection and restoration: progress and challenges. Resources 2:213-230.

Barrington, K., Chopin, T. \& Robinson, S. 2009. Integrated multi-trophic aquaculture (IMTA) in marine temperate waters. In Soto, D. (Ed.) Integrated Mariculture: A Global Eeview. FAO Fisheries and Aquaculture Technical Paper, No. 529. Food and Agriculture Organization of the United Nations, Rome, pp. 7-46.

Bjerregaard, R., Valderrama, D., Radulovich, R., Diana, J., Capron, M., Mckinnie, C. A., Cedric, M., Hopkins, K., Yarish, C., Goudey, C. \& Forster, J. 2016. Seaweed aquaculture for food security, income generation and environmental health in Tropical Developing Countries. Report \#107147. Available from: http://documents.worldbank. org/curated/en/947831469090666344/Seaweed-aquaculture-for-food-security-income-generation-and-environmental-health-in-Tropical-Developing-Countries; jsessionid=4sLY8b149Hwa-8ramT5do35G. Accessed Jan 23, 2017.

Blouin, N. A., Brodie, J. A., Grossman, A. C., Xu, P. \& Brawley, S. H. 2011. Porphyra: a marine crop shaped by stress. Trends Plant Sci. 16:29-37.

Broch, O. J., Ellingsen, I. H., Forbord, S., Wang, X., Volent, Z., Alver, M. O., Handå, A., Andresen, K., Slagstad, D., Reitan, K. I., Olsen, Y. \& Skjermo, J. 2013. Modelling the cultivation and bioremediation potential of the kelp Saccharina latissima in close proximity to an exposed salmon farm in Norway. Aquac. Environ. Interact. 4:186-206.

Buck, B. H. \& Buchholz, C. M. 2004. The offshore-ring: a new system design for the open ocean aquaculture of macroalgae. J. Appl. Phycol. 16:355-368.

Buschmann, A. H., Hernández-González, M. C. \& Varela, D. A. 2008a. Seaweed future cultivation in Chile: perspectives and challenges. Int. J. Environ. Pollut. 33:432-456.

Buschmann, A. H., Prescott, S., Potin, P., Faugeron, S., Vásquez, J. A., Camus, C., Infante, J., Hernández-González, M. C., Gutíerrez, A. \& Varela, D. A. 2014. The status of kelp exploitation and marine agronomy, with emphasis on Macrocystis pyrifera, in Chile. Adv. Bot. Res. 71:161-188.

Buschmann, A. H., Varela, D. A., Hernández-González, M. C. \& Huovinen, P. 2008b. Opportunities and challenges for the development of an integrated seaweed-based aqua- culture activity in Chile: determining the physiological capabilities of Macrocystis and Gracilaria as biofilters. J. Appl. Phycol. 20:571-577.

Caines, S., Manríquez-Hernández, J. A., Duston, J., Corey, P. \& Garbary, D. J. 2014. Intermittent aeration affects the bioremediation potential of two red algae cultured in finfish effluent. J. Appl. Phycol. 26:2173-2181.

Camus, C., Ballerino, P., Delgado, R., Olivera-Nappa, Á., Leyton, C. \& Buschmann, A. H. 2016. Scaling up bioethanol production from the farmed brown macroalgae Macrocystis pyrifera in Chile. Biofuels Bioprod. Biorefin. 10:673-685.

Chen, T. T., Lin, C. M., Chen, M. J., Lo, J. H., Chiou, P. P., Gong, H. Y., Wu, J. L., Chen, M. H. C. \& Yarish, C. 2015. Principles and application of transgenic technology in marine organisms. In Kim, S. -K. (Ed.) Handbook of Marine Biotechnology. Springer, Berlin, pp. 387-412.

Chopin, T., Robinson, S. M. C., Troell, M., Neori, A., Buschmann, A. H. \& Fang, J. 2008. Multitrophic integration for sustainable marine aquaculture. In Jørgensen, S. E. \& Fath, B. D. (Eds.) Encyclopedia of Ecolog. Vol. 3. Ecological Engineering. Elsevier, Oxford, pp. 2463-2475.

Chopin, T., Yarish, C., Wilkes, R., Belyea, E., Lu, S. \& Mathieson, A. 1999. Developing Porphyra/salmon integrated aquaculture for bioremediation and diversification of the aquaculture industry. J. Appl. Phycol. 11:463-472.

Chung, I. K, Kang, Y. H., Yarish, C., Kraemer, G. P. \& Lee, J. A. 2002. Application of seaweed cultivation to the bioremediation of nutrient-rich effluent. Algae 17:187-194.

Corey, P., Kim, J. K., Duston, J. \& Garbary, D. J. 2014. Growth and nutrient uptake by Palmaria palmata integrated with Atlantic halibut in a land-based aquaculture system. Algae 29:35-45.

Corey, P., Kim, J. K., Garbary, D. J., Prithiviraj, B. \& Duston, J. 2012. Bioremediation potential of Chondrus crispus (Basin Head) and Palmaria palmata: effect of temperature and high nitrate on nutrient removal. J. Appl. Phycol. 24:441-448.

Correa, T., Gutiérrez, A., Flores, R., Buschmann, A. H., Cornejo, P. \& Bucarey, C. 2016. Production and economic assessment of giant kelp Macrocystis pyrifera cultivation for abalone feed in the south of Chile. Aquac. Res. 47:698-707.

Costanza, R., de Groot, R., Sutton, P., van der Ploeg, S., Anderson, S. J., Kubiszewski, I., Farber, S. \& Turner, R. K. 2014. Changes in the global value of ecosystem services. Glob. Environ. Change 26:152-158.

Cottier-Cook, E. J., Nagabhatla, N., Badis, Y., Campbell, M. L., Chopin, T., Dai, W., Fang, J., He, P., Hewitt, C. L., Kim, G. H., Huo, Y., Jiang, Z., Kema, G., Li, X., Liu, F., Liu, H., 
Liu, Y., Lu, Q., Luo, Q., Mao, Y., Msuya, F. E., Rebours, C., Shen, H., Stentiford, G. D., Yarish, C., Wu, H., Yang, X., Zhang, J., Zhou, Y. \& Gachon, C. M. M. 2016. Safeguarding the future of the global seaweed aquaculture industry. United Nation University (INWEH) and Scottish Association for Marine Science Policy Brief, South Hamilton, ON, 12 pp.

Dean, P. R. \& Hurd, C. L. 2007. Seasonal growth, erosion rates, and nitrogen and photosynthetic ecophysiology of Undaria pinnatifida (Heterokontophyta) in southern New Zealand. J. Phycol. 43:1138-1148.

Dillehay, T. D., Ramírez, C., Pino, M., Collins, M. B., Rossen, J. \& Pino-Navarro, J. D. 2008. Monte Verde: seaweed, food, medicine, and the peopling of South America. Science 320:784-786.

FAO (Food and Agriculture Organization of the United Nations). 2015. World fertilizer trends and outlook to 2019. Available from: http://www.fao.org/3/a-i5627e.pdf. Accessed Jan 23, 2017.

FAO (Food and Agriculture Organization of the United Nations). 2017. The state of world fisheries and aquaculture. Available from: http:/ / www.fao.org/fishery/en. Accessed Jan 23, 2017.

Fowler-Walker, M. J., Wernberg, T. \& Connell, S. D. 2006. Differences in kelp morphology between wave sheltered and exposed localities: morphologically plastic or fixed traits? Mar. Biol. 148:755-767.

Gerard, V. A. 1997. The role of nitrogen nutrition in high-temperature tolerance of the kelp, Laminaria saccharina (Chromophyta). J. Phycol. 33:800-810.

Getchis, T. S., Rose, C. M., Carey, D., Kelly, S., Bellantuono, K. \& Francis, P. 2008. A guide to marine aquaculture permitting in Connecticut. Connecticut Sea Grant College Program, Groton, CT, 140 pp.

Gevaert, F., Davoult, D., Creach, A., Kling, R., Janquin, M. -A., Seuront, L. \& Lemoine, Y. 2001. Carbon and nitrogen content of Laminaria saccharina in the eastern English Channel: biometrics and seasonal variations. J. Mar. Biol. Assoc. U. K. 81:727-734.

Gorman, L., Kraemer, G. P., Yarish, C., Boo, S. M. \& Kim, J. K. 2017. The effects of temperature on the growth and nitrogen content of Gracilaria vermiculophylla and Gracilaria tikvahiae from LIS, USA. Algae 32:57-66.

Guillemin, M. L., Faugeron, S., Destombe, C., Viard, F., Correa, J. A. \& Valero, M. 2008. Genetic variation in wild and cultivated populations of the haploid-diploid red alga Gracilaria chilensis: how farming practices favor asexual reproduction and heterozygosity. Evolution 62:15001519.

Guiry, M. D. \& Guiry, G. M. 2016. AlgaeBase. World-wide electronic publication, National University of Ireland, Galway. Available from: http://www.algaebase.org. Accessed Jun 21, 2016.

Hafting, J. T., Craigie, J. S., Stengel, D. B., Loureiro, R. R., Buschmann, A. H., Yarish, C., Edwards, M. D. \& Critchley, A. T. 2015. Prospects and challenges for industrial production of seaweed bioactives. J. Phycol. 51:821-837.

Han, T., Kong, J. A., Kang, H. G., Kim, S. J., Jin, G. S., Choi, H. \& Brown, M. T. 2011. Sensitivity of spore germination and germ tube elongation of Saccharina japonica to metal exposure. Ecotoxicology 20:2056-2068.

Hanisak, M. D. 1987. Cultivation of Gracilaria and other macroalgae in Florida for energy production. In Bird, K. T. \& Benson, P. H. (Eds.) Seaweed Cultivation for Renewable Resources. Elsevier, New York, pp. 191-218.

Hanisak, M. D. \& Ryther, J. H. 1984. Cultivation biology of Gracilaria tikvahiae in the United States. Hydrobiologia 116/117:295-298.

Hayashi, L., Hurtado, A. Q., Msuya, F. E., Bleicher-Lhonneur, G. \& Critchley, A. T. 2010. A review of Kappaphycus farming: prospects and constraints. In Israel, A., Einav, R. \& Seckbach, J. (Eds.) Seaweeds and Their Role in Globally Changing Environments: Cellular Origin, Life in Extreme Habitats and Astrobiology. Springer, New York, pp. 251283.

He, P., Xu, S., Zhang, H., Wen, S., Dai, Y., Lin, S. \& Yarish, C. 2008. Bioremediation efficiency in removal of dissolved nutrients by the red seaweed, Porphyra yezoensis, cultivated in open sea. Water Res. 42:1281-1289.

He, P. \& Yarish, C. 2006. The developmental regulation of mass cultures of free-living conchocelis for commercial net seeding of Porphyra leucosticta from Northeast America. Aquaculture 257:373-381.

Hou, J. \& Jin, Y. 2005. The healing power of Chinese herbs and medicinal recipes. Haworth Press, Inc., New York, 662 pp.

Hu, C., Li, D., Chen, C., Ge, J., Muller-Karger, F. E., Liu, J., Yu, F. \& He, M. -X. 2010. On the recurrent Ulva prolifera blooms in the Yellow Sea and East China Sea. J. Geophys. Res. 115:C05017.

Huo, Y., Han, H., Hua, L., Wei, Z., Yu, K., Shi, H., Kim, J. K., Yarish, C. \& He, P. 2016. Tracing the origin of green macroalgal blooms based on the large scale spatio-temporal distribution of Ulva microscopic propagules and settled mature Ulva vegetative thalli in coastal regions of the Yellow Sea, China. Harmful Algae 59:91-99.

Hurtado, A. Q., Critchley, A. T., Trespoey, A. \& Bleicher Lhonneur, G. 2006. Occurrence of Polysiphonia epiphytes in Kappaphycus farms at Calaguas Is., Camarines Norte, Phillippines. J. Appl. Phycol. 18:301-306.

Hwang, E. K., Cho, Y. C. \& Sohn, C. H. 1998. Reuse of holdfasts 
in Hizikia cultivation. J. Korean Fish. Soc. 32:112-116.

Hwang, E. K., Gong, Y. G., Hwang, I. -K., Park, E. -J. \& Park, C. S. 2013. Cultivation of the two perennial brown algae Ecklonia cava and E. stolonifera for abalone feeds in Korea. J. Appl. Phycol. 25:825-829.

Hwang, E. K., Gong, Y. G. \& Park, C. S. 2012. Cultivation of a hybrid of free-living gametophytes between Undariopsis peterseniana and Undaria pinnatifida: morphological aspects and cultivation period. J. Appl. Phycol. 24:401-408.

Hwang, E. K., Ha, D. S., Baek, J. M., Wee, M. Y. \& Park, C. S. $2006 a$. Effects of $\mathrm{pH}$ and salinity on the cultivated brown alga Sargassum fulvellum and associated animals. Algae 21:317-321

Hwang, E. K., Park, C. S. \& Baek, J. M. 2006b. Artificial seed production and cultivation of the edible brown alga, Sargassum fulvellum (Turner) C. Agardh: developing a new species for seaweed cultivation in Korea. J. Appl. Phycol. 18:251-257.

Johnson, R. B., Kim, J. K., Armbruster, L. C. \& Yarish, C. 2014. Nitrogen allocation of Gracilaria tikvahiae grown in urbanized estuaries of Long Island Sound and New York City, USA: a preliminary evaluation of ocean farmed Gracilaria for alternative fish feeds. Algae 29:227-235.

Kawashima, Y. \& Tokuda, H. 1993. Regeneration from the callus of Undaria pinnatifida (Harvey) Suringar (Laminariales, Phaeophyta). Hydrobiologia 260/261:385-389.

Kerrison, P. D., Stanley, M. S., Edwards, M. D., Black, K. D. \& Hughes, A. D. 2015. The cultivation of European kelp for bioenergy: site and species selection. Biomass Bioenergy 80:229-242.

Kim, G. H., Moon, K. -H., Kim, J. -Y., Shim, J. \& Klochkova, T. A. 2014a. A revaluation of algal diseases in Korean $P y$ ropia (Porphyra) sea farms and their economic impact. Algae 29:249-265.

Kim, J. K., Duston, J., Corey, P. \& Garbary, D. J. 2013a. Marine finfish effluent bioremediation: effects of stocking density and temperature on nitrogen removal capacity of Chondrus crispus and Palmaria palmata (Rhodophyta). Aquaculture 414-415:210-216.

Kim, J. K., Kottuparambil, S., Moh, S. H., Lee, T. K., Kim, Y. -J., Rhee, J. -S., Choi, E. -M., Kim, B. H., Yu, Y. J., Yarish, C. \& Han, T. 2015a. Potential applications of nuisance microalgal blooms. J. Appl. Phycol. 27:1223-1234.

Kim, J. K., Kraemer, G. P., Neefus, C. D., Chung, I. K. \& Yarish, C. 2007. Effects of temperature and ammonium on growth, pigment production and nitrogen uptake by four species of Porphyra (Bangiales, Rhodophyta) native to the New England coast. J. Appl. Phycol. 19:431-440.

Kim, J. K., Kraemer, G. P. \& Yarish, C. 2013b. Emersion induces nitrogen release and alteration of nitrogen metabolism in the intertidal genus Porphyra. PLos ONE 8:e69961.

Kim, J. K., Kraemer, G. P. \& Yarish, C. 2014b. Field scale evaluation of seaweed aquaculture as a nutrient bioextraction strategy in Long Island Sound and the Bronx River Estuary. Aquaculture 433:148-156.

Kim, J. K., Kraemer, G. P. \& Yarish, C. 2015b. Use of sugar kelp aquaculture in Long Island Sound and the Bronx River Estuary for nutrient extraction. Mar. Ecol. Prog. Ser. 531:155-166.

Kim, J. K., Mao, Y., Kraemer, G. \& Yarish, C. 2015c. Growth and pigment content of Gracilaria tikvahiae McLachlan under fluorescent and LED lighting. Aquaculture 436:5257.

Kim, J. K. \& Yarish, C. 2014. Development of a sustainable land-based Gracilaria cultivation system. Algae 29:217225.

Kim, J. K., Yarish, C. \& Pereira, R. 2016. Tolerances to hypoosmotic and temperature stresses in native and invasive species of Gracilaria (Rhodophyta). Phycologia 55:257264.

Koehl, M. A. R., Silk, W. K., Liang, H. \& Mahadevan, L. 2008. How kelp produce blade shapes suited to different flow regimes: a new wrinkle. Integr. Comp. Biol. 48:834-851.

Kraemer, G. P., Kim, J. K. \& Yarish, C. 2014. Seaweed aquaculture: bioextraction of nutrients to reduce eutrophication. Association of Massachusetts Wetland Scientists Newsletter 89:16-17.

Langan, R. \& Horton, F. 2005. Design, operation and economics of submerged longline mussel culture in the open ocean. Bull. Aquac. Assoc. Can. 103:11-20.

Largo, D. B., Fukami, K. \& Nishijima, T. 1995. Occasional pathogenic bacteria promoting ice-ice disease in the carrageenan-producing red algae Kappaphycus alvarezii and Eucheuma denticulatum (Solieriaceae, Gigartinales, Rhodophyta). J. Appl. Phycol. 7:545-554.

Levine, I. A. \& Sahoo, D. 2010. Porphyra: harvesting gold from the sea. I.K. International Publihing House Pvt. Ltd., New Delhi, 92 pp.

Li, X., Cong, Y., Yang, G., Shi, Y., Qu, S., Li, Z., Wang, G., Zhang, Z., Luo, S., Dai, H., Xie, J., Jiang, G., Liu, J. \&Wang, T. 2007. Trait evaluation and trial cultivation of Dongfang No. 2, the hybrid of a male gametophyte clone of Laminaria longissima (Laminariales, Phaeophyta) and a female one of L. japonica. J. Appl. Phycol. 19:139-151.

Li, X., Zhang, Z., Qu, S., Liang, G., Sun, J., Zhao, N., Cui, C., Cao, Z., Li, Y., Pan, J., Yu, S., Wang, Q., Li, X., Luo, S., Song, S., Guo, L. \& Yang, G. 2016. Improving seedless kelp (Saccharina japonica) during its domestication by hybridizing gametophytes and seedling-raising from sporo- 
phytes. Sci. Rep. 6:21255.

Lindell, S., Green-Beach, E., Bailey, D., Beals, M., Kim, J. K. \& Yarish, C. 2015. Multi-cropping seaweed Gracilaria tikvahiae with oysters for nutrient bioextraction and sea vegetables in Waquoit Bay, MA. In National Shellfisheries Association 107th Annual Meeting, National Shellfisheries Association, Monterey, CA.

Liu, D., Keesing, J. K., Xing, Q. \& Shi, P. 2009. World's largest macroalgal bloom caused by expansion of seaweed aquaculture in China. Mar. Pollut. Bull. 58:888-895.

Marinho, G. S., Holdt, S. L., Birkeland, M. J. \& Angelidaki, I. 2015. Commercial cultivation and bioremediation potential of sugar kelp, Saccharina latissima, in Danish waters. J. Appl. Phycol. 27:1963-1973.

Mathieson, A. C., Hehre, E. J., Dawes, C. J. \& Neefus, C. D. 2008. An historical comparison of seaweed populations from Casco Bay, Maine. Rhodora 110:1-102.

McVey, J. P., Stickney, R. R., Yarish, C. \& Chopin, T. 2002. Aquatic polyculture balanced ecosystem management: new paradigms for seafood production. In Stickney, R. R. \& McVey, J. P. (Eds.) Responsible Marine Aquaculture. CABI Publishing, Wallingford, pp. 91-104.

Miura, A. 1984. A new variety and a new form of Porphyra (Bangiales, Rhodophyta) from Japan: Porphyra tenera Kjellman var. tamatsuensis Miura, var. nov. and $P$. yezoensis Ueda form. narawaensis Miura, form. nov. J. Tokyo Univ. Fish. 71:1-37.

Mumford, T. F. \& Miura, A. 1988. Porphyra as food: cultivation and economics. In Lembi, C. A. \& Waaland, J. R. (Eds.) Algae and Human Affairs. Cambridge University Press, London, pp. 87-117.

NASA. 2017. NASA, NOAA data show 2016 warmest year on record globally. Available from: https://www.nasa.gov/ press-release/nasa-noaa-data-show-2016-warmestyear-on-record-globally. Accessed Jan 12, 2017.

Neori, A., Chopin, T., Troell, M., Buschmann, A. H., Kraemer, G. P., Halling, C., Shpigel, M. \& Yarish, C. 2004. Integrated aquaculture: rationale, evolution and state of the art emphasizing seaweed biofiltration in modern aquaculture. Aquaculture 231:361-391.

Neori, A., Troell, M., Chopin, T., Yarish, C., Critchley, A. \& Buschmann, A. H. 2007. The need for a balanced ecosystem approach to blue revolution aquaculture. Environment 49:36-43.

Niwa, K., Iida, S., Kato, A., Kawai, H., Kikuchi, N., Kobiyama, A. \& Aruga, Y. 2009. Genetic diversity and introgression in two cultivated species (Porphyra yezoensis and Porphyra tenera) and closely related wild species of Porphyra (Bangiales, Rhodophyta). J. Phycol. 45:493-502.

Oliveira, E. C., Alveal, K. \& Anderson, R. J. 2000. Mariculture of the agar-producing Gracilarioid red algae. Rev. Fish. Sci. 8:345-377.

Park, J., Jin, G. -S., Hwang, M. S., Brown, M. T. \& Han, T. 2016. Toxicity tests using the kelp Undaria pinnatifida for heavy metal risk assessment. Toxicol. Environ. Health. Sci. 8:86-95.

Park, J., Kim, J. K., Kong, J. -A., Depuydt, S., Brown, M. T. \& Han, T. 2017. Implications of rising temperatures for gametophyte performance of two kelp species from Arctic waters. Bot. Mar. 60:39-48.

Patwary, M. U. \& van der Meer, J. P. 1992. Genetic and breeding of cultivated seaweeds. Algae 7:281-318.

Peng, Y., Xie, E., Zheng, K., Fredimoses, M., Yang, X., Zhou, X., Wang, Y., Yang, B., Lin, X., Liu, J. \& Liu, Y. 2013. Nutritional and chemical composition and antiviral activity of cultivated seaweed Sargassum naozhouense Tseng et Lu. Mar. Drugs 11:20-32.

Pereira, R. \&Yarish, C. 2008. Mass production of marine macroalgae. In Jørgensen, S. E. \& Fath, B. D. (Eds.) Encyclopedia of Ecology. Vol. 3. Ecological Engineering. Elsevier, Oxford, pp. 2236-2247.

Pereira, R. \& Yarish, C. 2010. The role of Porphyra in sustainable culture systems: physiology and applications. In Israel, A. \& Einav, R. (Eds.) Role of Seaweeds in a Globally Changing Environment. Springer Publishers, New York, pp. 339-354.

Pereira, R., Yarish, C. \& Critchley, A. T. 2013. Seaweed aquaculture for human foods in land based and IMTA systems. In Meyers, R. A. (Ed.) Encyclopedia of Sustainability Science and Technology. Springer, New York, pp. 9109-9128.

Qi, Z., Liu, H., Li, B., Mao, Y., Jiang, Z., Zhang, J. \& Fang, J. 2010. Suitability of two seaweeds, Gracilaria lemaneiformis and Sargassum pallidum, as feed for the abalone Haliotis discus hannai Ino. Aquaculture 300:189-193.

Raikar, S. V., Ima, M. \& Fujita, Y. 2001. Effects of temperature, salinity and light intensity on the growth of Gracilaria spp. (Gracilariales, Rhodophyta) from Japan, Malaysia and India. Indian J. Mar. Sci. 30:98-104.

Rawson, M. V. Jr., Chen, C., Ji, R., Zhu, M., Wang, D., Wang, L., Yarish, C., Sullivan, J. B., Chopin, T. \& Carmona, R. 2002. Understanding the interaction of extractive and fed aquaculture using ecosystem modeling. In Stickney, R. R. \& McVey, J. P. (Eds.) Responsible Marine Aquaculture. CABI Publishing, Wallingford, pp. 263-296.

Redmond, S., Green, L., Yarish, C., Kim, J. \& Neefus, C. $2014 a$. New England seaweed culture handbook: nursery systems. Connecticut Sea Grant CTSG-14-01. Available from: http://seagrant.uconn.edu/publications/aquaculture/handbook.pdf. Accessed Jan 23, 2017.

Redmond, S., Kim, J. K., Yarish, C., Pietrak, M. \& Bricknell, I. 
2014b. Culture of Sargassum in Korea: techniques and potential for culture in the U.S. Orono, ME: Maine Sea Grant College Program. Available from: http://seagrant. umaine.edu/extension/korea-aquaculture. Accessed Jan 23, 2017.

Rensel, J., Bright, K., King, G. \& Siegrist, Z. 2011. Integrated fish-shellfish mariculture in Puget Sound. NOAA Final report. 3-31-2011. NA08OAR4170860. NOAA National Marine Aquaculture Initiative, Rensel Associates, Arlington, WA, 82 pp.

Robertson-Andersson, D. V., Wilson, D. T., Bolton, J. J., Anderson, R. J. \& Maneveldt, G. W. 2009. Rapid assessment of tissue nitrogen in cultivated Gracilaria gracilis (Rhodophyta) and Ulva lactuca (Chlorophyta). Afr. J. Aquat. Sci. 34:169-172.

Robinson, N., Winberg, P. \& Kirkendale, L. 2013. Genetic improvement of macroalgae: status to date and needs for the future. J. Appl. Phycol. 25:703-716.

Rose, J. M., Bricker, S. B., Deonarine, S., Ferreira, J. G., Getchis, T., Grant, J., Kim, J. K., Krumholz, J. S., Kraemer, G. P., Stephenson, K., Wikfors, G. H. \& Yarish, C. 2015. Nutrient bioextraction. In Meyers, R. A. (Ed.) Encyclopedia of Sustainability Science and Technology. Springer, New York, pp. 1-33.

Sahoo, D. \& Ohno, M. 2003. Culture of Kappaphycus alvarezii in deep water and nitrogen enriched medium. Bull. Mar. Sci. Fish. 22:89-96.

Sahoo, D. \& Yarish, C. 2005. Mariculture of seaweeds. In Andersen, R. A. (Ed.) Phycological Methods: Algal Culturing Techniques. Academic Press, New York, pp. 219-237.

Schaffelke, B. 2001. Surface alkaline phosphatase activities of macroalgae on coral reefs of the central Great Barrier Reef, Australia. Coral Reefs 19:310-317.

Schaffelke, B. \& Klumpp, D. W. 1998. Nutrient-limited growth of the coral reef macroalga Sargassum baccularia and experimental growth enhancement by nutrient addition in continuous flow culture. Mar. Ecol. Prog. Ser. 164:199211.

Shin, J. -A. 1999. Crossing between Porphyra yezoensis and $P$. tenera. Algae 14:73-77.

Shin, J. -A. 2003. Inheritance mode of some characters of Porphyra yezoensis (Bangiales, Rhodophyta) II. Yield, photosynthetic pigment content, red rot disease-resistance, color, luster and volatile sulfur compounds concentration. Algae 18:83-88.

SINTEF. 2014. A new Norwegian bioeconomy based on cultivation and processing of seaweeds: opportunities and research and development needs. SINTEF Fisheries and Aquaculture, Norway. Available from: http://www. innovasjonnorge.no/contentassets/95273c625e1c4b 4caf8b4d0a36020dc0/2014-sintef---seaweed-in-thebioeconomy.pdf. Accessed Jan 23, 2017.

Sohn, C. H. 1998. The seaweed resources of Korea. In Critchley, A. T. \& Ohno, M. (Eds.) Seaweed Resources of the World. Japan International Cooperation Agency, Yokosuka, pp. 15-33.

Stekoll, M. S. \& Peeples, T. N. 2016. Marine plant aquaculture in southeast Alaska. Annual Meeting of the Phycological Society of America. pp. 38-39. Available from: http:// staticl.squarespace.com/static/543d47aee4b0f40897fde 705/t/5790efa11b631be8a7alf64a/1469116323834/ Full+Final+Program.pdf. Accessed Jan 23, 2017.

Vairappan, C. A., Chung, C. S., Hurtado, A. Q., Soya, F. E., Lhonneur, G. B. \& Critchley, A. 2009. Distribution and symtoms of epiphytic infection in major carrageenophyte-producing farms. In Nineteenth International Seaweed Symposium, Vol. 2, Springer, Amsterdam, pp. 27-33.

Valderrama, D., Cai, J., Hishamunda, N., Ridler, N., Neish, I. C., Hurtado, A. Q., Msuya, F. E., Krishnan, M., Narayanakumar, R., Kronen, M., Robledo, D., Gasca-Leyva, E. \& Fraga, J. 2015. The economics of Kappaphycus seaweed cultivation in developing countries: a comparative analysis of farming systems. Aquac. Econ. Manag. 19:251-277.

Valero, M., Guillemin, M. -L., Destombe, C., Jacquemin, B., Gachon, C. M. M., Badis, Y., Buschmann, A. H., Camus, C. \& Faugeron, S. 2017. Perspectives on domestication research for sustainable seaweed aquaculture. Perspect. Phycol. Advanced online publication. https://doi. org/10.1127/pip/2017/0066.

Weinberger, F., Buchholz, B., Karez, R. \& Wahl, M. 2008. The invasive red alga Gracilaria vermiculophylla in the Baltic Sea: adaptation to brackish water may compensate for light limitation. Aquat. Biol. 3:251-264.

Wells, M. L., Potin, P., Craigie, J. S., Raven, J. A., Merchabnt, S. S, Helliwell, K. E., Smith, A. G., Camire, M. E. \& Brawley, S. H. 2016. Algae as nutritional and functional food sources: revisiting our understanding. J. Appl. Phycol. Advanced online publication. https://doi/org/10.1007/ s10811-016-0974-5.

Wu, H., Huo, Y., Han, F., Liu, Y. \& He, P. 2015. Bioremediation using Gracilaria chouae co-cultured with Sparus macrocephalus to manage the nitrogen and phosphorous balance in an IMTA system in Xiangshan Bay, China. Mar. Pollut. Bull. 91:272-279.

Wu, H., Kim, J. K., Huo, Y., Zhang, J. \& He, P. 2017. Nutrient removal ability of seaweeds on Pyropia yezoensis aquaculture rafts in China's radial sandbanks. Aquat. Bot. 137:72-79. 
Xie, E. Y., Liu, D. C., Jia, C., Chen, X. L. \& Yang, B. 2013. Artificial seed production and cultivation of the edible brown alga Sargassum naozhouense Tseng et Lu. J. Appl. Phycol. 25:513-522.

Yokoya, N. S., Hirotaka, K., Obika, H. \& Litamura, T. 1999. Effects of environmental factors and plant growth regulators on growth of the red alga Gracilaria vermiculophylla from Shikoku Island, Japan. Hydrobiologia 398/399:339347.
Zhang, J., Huo, Y., Wu, H., Yu, K., Kim, J. K., Yarish, C., Qin, Y., Liu, C., Xu, R. \& He, P. 2014. The origin of the Ulva macroalgal blooms in the Yellow Sea in 2013. Mar. Pollut. Bull. 89:276-283.

Zhang, J., Kim, J. K., Yarish, C. \& He, P. 2016. The expansion of Ulva prolifera O.F. Müller macroalgal blooms in the Yellow Sea, PR China, through asexual reproduction. Mar. Pollut. Bull. 104:101-106. 